\title{
Loss Assessment of Qualitative and Quantitative Composition of The Middle Class in Terms of Sustainable and Digital Development
}

\author{
By Olga Novikova ${ }^{1}$, Olena Khandii ${ }^{2}$, Larisa Shamileva ${ }^{1}$, Inna Semenenko ${ }^{2}$, \\ Iaroslav Burko ${ }^{2}$
}

\begin{abstract}
The article studies the trends of quantitative changes in social class in Ukraine as an important factor of sustainable socio-economic development. The use of a complex criterion for determining the core of the middle class in the population structure is substantiated. It takes into account the level of income, self-identification, and qualitative characteristics. The article proves the hypothesis of conformity of the distribution of households by average per capita equivalent income to the theoretical log-normal distribution. The paper provides the quantitative characteristics of the impact of digitalization on the size of the middle class, determines the consequences of distribution of information technology for its existence. The main directions and tools for influence are proposed to ensure the conditions for the formation, development, and growth of the middle class in modern society, and to achieve a high level of economic development and welfare of the population.
\end{abstract}

Keywords: middle class, sustainable development, digitalization of the economy, loss of quantitative composition of the middle class, middle class criteria

\section{Introduction}

The middle class as a component of the social stratification of society is considered as a social group that has a stable income sufficient to meet material and social needs. Welfare inherent in the middle class provides opportunities for a decent quality of life, so it has higher social stability in terms of achieving sustainable development. Aristotle also argued that the larger that social stratum was, the more stable society itself would be [3].

The social significance of the middle class is determined by its main functions including economic, socio-political, socio-psychological, and others. In terms of the economic function, the role and importance of this social group are to create a stratum of the population, which ranks between the rich and the poor in terms of income. Thus it is the main generator of domestic demand determining the level of investment and employment and is a factor of economic growth. Being the main tax donor, the middle class provides high productivity, stimulates entrepreneurship, motivates the production and dissemination of knowledge. It is also a source of reproduction of skilled manpower, growth, preservation of human potential and human capital, opportunities for sustainable development. 
In the context of political and social functions, the middle class is seen as a major factor in social stability. It creates a demand for political and social institutions, acts as social support and driving force of democratic transformation and reform, a factor of the civil society development. The socio-psychological function is related to the preservation and dissemination of basic values of the democratic society. Representatives of this social stratum are carriers and generators of progressive thinking and purposefulness, cultural integrators of society [14].

Research on the problems of social stratification with determining the essence, significance, and the role of the middle class, its place in ensuring sustainable development and social stability have been covered in scientific publications of Ukrainian and foreign scientists. The works of E. Libanova, L. Cherenko [12], O. Alexandrova [1], S. Makeiev [13], I. Bulieiev [5], T. Tkachenko [27], and others consider the main conditions and factors of the middle class formation in Ukraine. Scientific works $[17 ; 18]$ widely cover the issues related to the determining and systematizing the criteria of the middle class identification. Foreign studies include the works of T. Zaslavska [29], A. Sobolev [21], A. Alekseenok [2], R. Balvociute [4], P. Rydzewski [19]. Due to the development and implementation of digitalization of the economy, and the spread of information and communication technology, the scientific publications of $\mathrm{R}$. Collins [7], A. Kolota, O. Gerasimenko [10; 11] consider the issues related to 'hollowing out of the middle class due to the manifestation of technological substitution'.

The study aims to analyse the main trends in the size and share of the middle class in Ukraine and substantiate the peculiarities of its formation under digitalization of the economy and sustainable development of society.

\section{Research Results}

Currently, there is no unambiguous definition of the concept of 'the middle class', its substantive characteristics, and criteria by which a particular social group can be attributed to it.

The main characteristics based on which the concept of the middle class is formed under conditions of sustainable development include $[17 ; 18 ; 21 ; 26]$ :

- property status (availability of property, its size);

- stable high income, which determines the structure of expenses and demand;

- high level of professional education and qualification that provides a certain social status and determine stereotypes of behaviour;

- special mentality, satisfaction with the status of belonging to the social group.

Based on the above characteristics, the following main criteria are used to distinguish the middle class:

- economic. These indicators characterize the average per capita income or expenses, the availability of a certain set of valuables, property, etc.;

- socio-economic. According to this criterion, the middle class includes the share of the population, which is the bearer of developed human capital and is determined by the level of education, the employment pattern, professional and qualification level. It also includes small and medium-sized businesses that receive dividends on their economic capital; 
- socio-psychological. It is based on the self-identification of a person who identifies himself/herself as the middle class;

- combinational or complex. Based on this approach, the main criteria are summarized, which include educational, professional and qualification, income and property levels with mandatory self-identification.

In each country, the list of criteria and their indicators differs, but in most countries the level of material security and the employment pattern are mandatory.

In the context of this study, the middle class is considered as a socio-economic category of structuring society, so the main criteria for its identification are the following:

- the level of material well-being;

- the level of education, professional and qualification status, the employment pattern;

- self-determination or self-identification.

In terms of the first criterion, the middle class includes the share of the population characterized by relatively high living standards and demand, a sufficient level of material well-being estimated per capita income (expenses), the availability of some property (car, own comfortable housing, etc.), and access to paid social services (education, medicine, leisure, etc.).

According to the educational, professional and qualification levels, the middle class can include people with higher (complete basic and incomplete) or vocational education, but not below, by professional groups, i.e., officials, managers, businessmen, specialists and professionals, employees engaged in intellectual and creative work.

The main indicators of the scale for determining the criteria are quite diverse, but they are mostly of interval character. In our opinion, based on the real economic situation in Ukraine, aiming to ensure comparability over time, as well as taking into account the availability of objective information, it is reasonable to use the following ones:

- three average quintiles of the distribution of households by the size of the average per capita equivalent total income, i.e., the share of persons whose income varies between the second and the fourth quintiles;

- median value of income, i.e., the share of the population with income from one to two of their median values;

- the share of the population whose daily total income varies from 10 to 45 USD (according to the recommendations of the World Bank (WB) 1 .

The given indicators mainly determine the content of the economic criterion.

The following ones are taken to identify the socio-economic criterion:

- the level of education, i.e., the share of the population aged 15 to 70 who have complete basic, and incomplete higher, as well as vocational education;

- the professional and qualification level, i.e., the share of the population aged 15 to 70 employed in professional groups, which include legislators, senior civil servants, heads, managers, professionals, specialists, technical staff, highly skilled workers with tools, and other categories;

- the third group of criteria defined as socio-psychological includes indicators of self-

\footnotetext{
${ }^{1}$ Some experts suggest determining these limits by the PPP of the national currency. The given limits of change in income (expenses) are based on recommendations of the World Bank (2007); representatives of the middle class should have an average annual income from 4000 (Brazil) to 17000 (Italy) USD [18].
} 
identification, i.e., the share of people who self-identify as middle class.

All these criteria and indicators for their determination have significant limitations and shortcomings primarily related to shadow income and incomplete records in official statistics. There is a significant level of uncertainty in terms of the qualitative criteria because workers with higher education and appropriate professional qualification are not always employed in high-income jobs and those corresponding to their social status. The situation with indicators of self-identification is quite ambiguous. According to the programme of sample surveys of households, respondents are asked to answer two questions, namely, 'Do you consider yourself to be the middle class, or well-off but not the middle class according to the welfare level estimation?' [23]. Based on the fact that according to the respondents, the desired income corresponding to the property status of the middle class is 3-5 times higher than the actual one, most respondents do not identify themselves as representatives of this social group. But in terms of content, individuals who belong to these two groups together correspond to the characteristics of the middle class.

In our opinion, among the variety of economic criteria by income, the most objective is the criterion according to which the middle class includes the share of the population that has an average per capita income in the range of 2-4 quintiles (Table 1).

Table 1. The share of the population that can be attributed to the middle class according to the above criteria

\begin{tabular}{|c|c|c|c|c|c|c|c|}
\hline \multirow{3}{*}{ Year } & \multicolumn{4}{|c|}{$\begin{array}{l}\text { The share of the population that meets the criteria } \\
\text { of the middle class, } \%\end{array}$} & \multicolumn{3}{|c|}{ Average monthly income, UAH } \\
\hline & \multicolumn{2}{|c|}{$\begin{array}{c}\text { average annual } \\
\text { equivalent total income } \\
\text { within }\end{array}$} & \multicolumn{2}{|c|}{ by self-identification } & \multirow[b]{2}{*}{ actual } & \multirow{2}{*}{$\begin{array}{l}\text { corresponds to } \\
\text { the property } \\
\text { status of the } \\
\text { middle class }\end{array}$} & \multirow{2}{*}{$\begin{array}{l}\text { exceeding the } \\
\text { desired and } \\
\text { actual income, } \\
\text { times }\end{array}$} \\
\hline & $\begin{array}{l}\text { from the } \\
\text { 2nd to the } \\
\text { 4th quintile }\end{array}$ & $\begin{array}{c}\text { from one to } \\
\text { two median } \\
\text { values }\end{array}$ & $\begin{array}{l}\text { refers to } \\
\text { the } \\
\text { middle } \\
\text { class }\end{array}$ & $\begin{array}{c}\text { refers to well- } \\
\text { off, but not to } \\
\text { the middle } \\
\text { class }\end{array}$ & & & \\
\hline 2010 & 40.0 & 46.9 & 1.5 & 38.2 & 1593.0 & 4391.0 & 2.8 \\
\hline 2011 & 40.0 & 52.0 & 0.8 & 36.8 & 1763.5 & 4887.0 & 2.8 \\
\hline 2012 & 40.6 & 47.0 & 0.9 & 31.2 & 1911.3 & 4585.5 & 2.4 \\
\hline 2013 & 40.5 & 43.0 & 0.8 & 31.2 & 2052.3 & 8798.0 & 4.3 \\
\hline 2014 & 40.4 & 43.5 & 0.8 & 28.5 & 2129.0 & 11340.0 & 5.3 \\
\hline 2015 & 42.1 & 52.0 & 0.7 & 27.0 & 2427.5 & 13846.0 & 5.7 \\
\hline 2016 & 41.8 & 52.7 & 0.5 & 25.0 & 2888.6 & 15420.0 & 5.3 \\
\hline 2017 & 40.0 & 50.0 & 0.6 & 28.7 & 3798.0 & 18152.0 & 4.8 \\
\hline 2018 & 39.9 & 50.0 & 0.9 & 27.9 & 4607.0 & 18700.0 & 4.1 \\
\hline 2019 & 39.6 & 42.8 & 1.1 & 33.6 & 5615.5 & 20224.0 & 3.6 \\
\hline 2020, incl. & - & - & - & - & - & - & - \\
\hline 1st half year & 35.5 & 26.8 & - & - & - & - & - \\
\hline 3rd quarter & 40.1 & 31.1 & - & - & 5991.5 & - & - \\
\hline
\end{tabular}

Source: calculated by the authors based on statistics provided in statistical collections of 2010-2020 [22; 23; 24; 257.

Over the last ten years, the share of the population that can be identified as the middle class by the quintile distribution criterion has been ranging from 39.6\% (2019) to $42.1 \%$ (2015) [22]. Approximately the same pattern has developed according to the median 
criterion, but as for the absolute value of this criterion, the middle class share is slightly bigger; the excess is $4.0-10.0 \%$. At the same time, it should be noted that according to these two criteria, since 2015, there has been a trend to reduction of the share of the population, which can be attributed to the middle class in terms of income.

It should be noted that in terms of self-identification, only about $1.0 \%$ of the population belongs to the middle class. In recent decades, this figure has been ranging from $0.5 \%$ (2016) to $1.5 \%$ (2010), and there is no clear trend towards its change. If one takes into account the share of those who consider themselves well-off, then this share generally varies in the range of $25.5 \%$ (2016) - 39.7\% (2010). Such a significant difference in terms of self-identification and economic criteria is due to the high requirements of respondents to the desired amount of income, which must correspond to the property status of the middle class. As it can be seen from the comparisons in Table 1, there is almost a fivefold excess of subjective desired estimates over actual income.

It is quite difficult to estimate the size of the middle class in Ukraine based on the WB criteria, especially if it is necessary to determine comparable indicators over a long period. This is due to rather low levels of household income. So, based on the differentiation of households by the income level presented in official statistics [22] and taking into account the exchange rate, such an assessment is possible only pointwise.

Based on these objective reasons, Table 2 shows the generalized indicators, which together constitute the content of a complex criterion for determining the share of the middle class in the structure of the population of Ukraine.

Table 2. Correlation of the share of the population, which belongs to the middle class according to given criteria, $\%$

\begin{tabular}{|l|c|c|c|c|c|c|c|}
\hline Criteria for middle class identification & 2010 & 2011 & 2014 & 2018 & 2019 & $\begin{array}{c}\text { 1st } \\
\text { half } \\
\text { year }\end{array}$ & $\begin{array}{c}3 \text { 3rd } \\
\text { quarter }\end{array}$ \\
\hline $\begin{array}{l}\text { 1. The share of the population with income within the second } \\
\text { or fourth quintile by the level of per capita equivalent income }\end{array}$ & 40.0 & 40.0 & 40.4 & 39.9 & 39.6 & 40.0 & 40.0 \\
\hline $\begin{array}{l}\text { 2. The share of the population with income from the median } \\
\text { to two-median value of per capita equivalent income }\end{array}$ & 46.9 & 52.0 & 43.5 & 50.0 & 42.8 & 42.8 & 41.9 \\
\hline $\begin{array}{l}\text { 3. The share of the population with an average daily income } \\
\text { in the range from 10 to 45 USD at the NBU exchange rate }\end{array}$ & $-*$ & 17.1 & 7.0 & $-*$ & 16.0 & 10.8 & 10.4 \\
\hline $\begin{array}{l}\text { 4. The share of the population with an average daily income } \\
\text { in the range from 10 to 45 USD by the PPP }\end{array}$ & 82.8 & 90.3 & 80.7 & 97.6 & 95.5 & 88.6 & 95.6 \\
\hline $\begin{array}{l}\text { 5. According to the criterion of self-identification } \\
\text { in total, including: }\end{array}$ & 39.7 & 37.6 & 29.3 & 28.8 & 34.7 & - & - \\
\hline - refers to the middle class & 1.5 & 0.8 & 0.8 & 0.9 & 1.1 & - & - \\
\hline - to well-off, but not the middle class & 38.2 & 36.8 & 28.5 & 27.9 & 33.6 & - & - \\
\hline $\begin{array}{l}\text { 6. The share of the population aged 15-70, which belongs to } \\
\text { the middle class by qualitative criteria: }\end{array}$ & & & & & & & \\
\hline -by educational level & 23.4 & 23.4 & 24.1 & 27.6 & 27.2 & - & - \\
\hline - by professional groups & 21.5 & 20.8 & 23.0 & 23.8 & 23.7 & - & - \\
\hline $\begin{array}{l}\text { 7. The share of the population aged 15-70, which belongs to } \\
\text { the middle class (core of the middle class) according to the } \\
\text { complex (combinational) criterion }\end{array}$ & 13.8 & 13.3 & 14.7 & 15.2 & 15.1 & - & - \\
\hline
\end{tabular}


* According to 'Household expenses and resources' statistical collections of data on the distribution of households by the level of per capita total income, taking into account the USD NBU exchange rate, it is impossible to correctly calculate the required indicators as of 2010 and 2018 [22; 23; 24; 25$].$

Source: calculated by the authors

According to all these criteria, there is no clear trend towards the change in the share of the middle class over the last decade. If the share of this social group is almost stable according to the quintile criterion, then there is a slight decrease about $4.0 \%$ according to the median values. The same trend has developed according to the criteria of selfidentification. At the same time, in terms of qualitative characteristics, such as education and employment by professional groups, there is a reverse trend, i.e., over the last ten years, the growth has ranged from 2.2 to $3.8 \%$ (Fig. 1). Estimates by the criteria recommended by the World Bank are rather uncertain and incomparable in time, which is primarily due to rather low income levels, significant exchange rate fluctuations. The available statistical information as of certain periods makes it impossible to determine them.

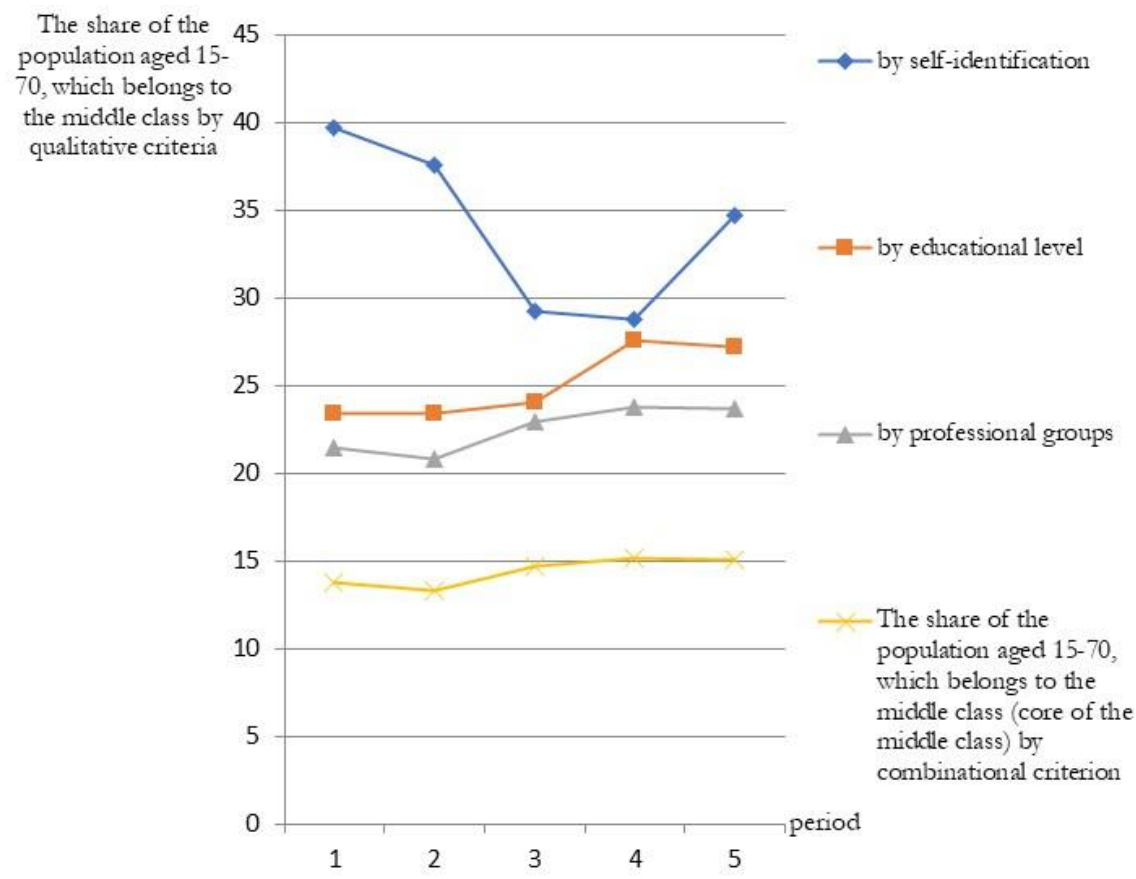

Figure 1. The share of the population aged 15-70, which belongs to the middle class

Source: developed by the authors according to Table 2.

At the same time, it is necessary to pay attention to the features and limitations related to the use of each of these criteria. For example, high income or income within three average quintiles is received by employees who do not always have an educational and professional level that meets the criteria of the middle class. On the other hand, a significant number of professionals and specialists (doctors, teachers, creative workers 
and other groups of employees with higher education) have income that do not fall within the economic criterion. Such features of employment and salary have developed in the national labour market $[15 ; 20]$. According to our calculations, under these conditions about two-thirds (63-65\%) of these categories can be attributed to the middle class $^{2}$.

Based on these real conditions and the distribution of employees by professional groups according to their diploma, we can assume that according to the complex criterion the real share of the middle class is formed at the intersection of the three given criteria, which most researchers and experts define as the core of the middle class (Fig. 2).

According to these estimates, the share of the middle class ranges from 13.3 to $15.1 \%$ of the adult population, which almost coincides with the results of some studies [17] and expert opinions [8]. Figure 2 visually presents a graphic model for determining the middle class. At the same time, the plane of intersection of the criteria corresponds to the content of the complex criterion and determines the core of the middle class ${ }^{3}$.

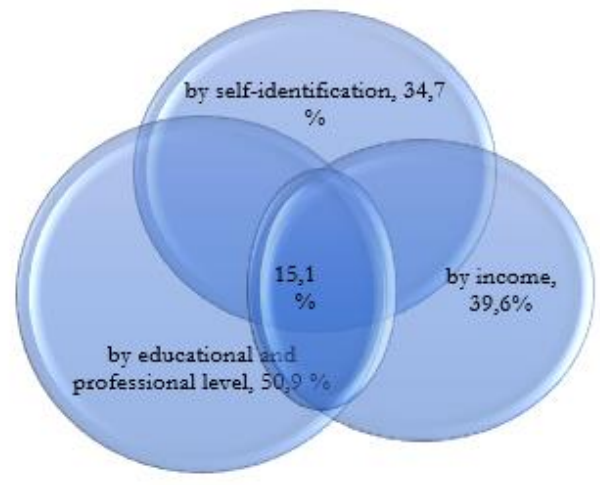

Figure 2. Graphic model for determining the middle class

Source: developed by the authors as of 2019 according to Table 2.

Modern transformations in the system of social and labour relations and in the labour market significantly affect the change in the social stratification of society, especially due to the implementation of information and communication technology. Determining the main trends of this change serves as a scientific rationale of the directions and mechanisms of forming a progressive social structure of society in terms of sustainable development.

Prospective estimates of the share of the middle class in the social structure of society are based on two methodological approaches that meet the content and requirements of the complex criterion:

-by economic, i.e., based on theoretical frequencies while keeping the law of distribution

${ }^{2}$ Estimates were conducted based on the distribution of employees by professional groups and specialty according to the diploma (certificate), and the distribution of economic activity of the population by profession, specialty according to the diploma (certificate) during 2018-2019 [24; 25].

3 The graphic model is developed by the technology of graphic representation of the composition of the middle strata of the population, which is given in paper [17]. 
of households by income developed in 2019, the share of the population is determined, which belongs to this social group by the quintile criterion;

-by qualitative, i.e., possible changes in the share of employees by professional groups are estimated under digitalization of the economy.

Based on the empirical distribution of households by per capita equivalent total income as of 2019, the hypothesis of its compliance with the theoretical log-normal distribution is confirmed with a probability of 0.975 (Fig. 3). According to the theoretical distribution, the share of the population that will have income within the determined average quintiles is about 40\%, and 46.3\% within the median criterion, which corresponds to the patterns that have developed over the past ten years.

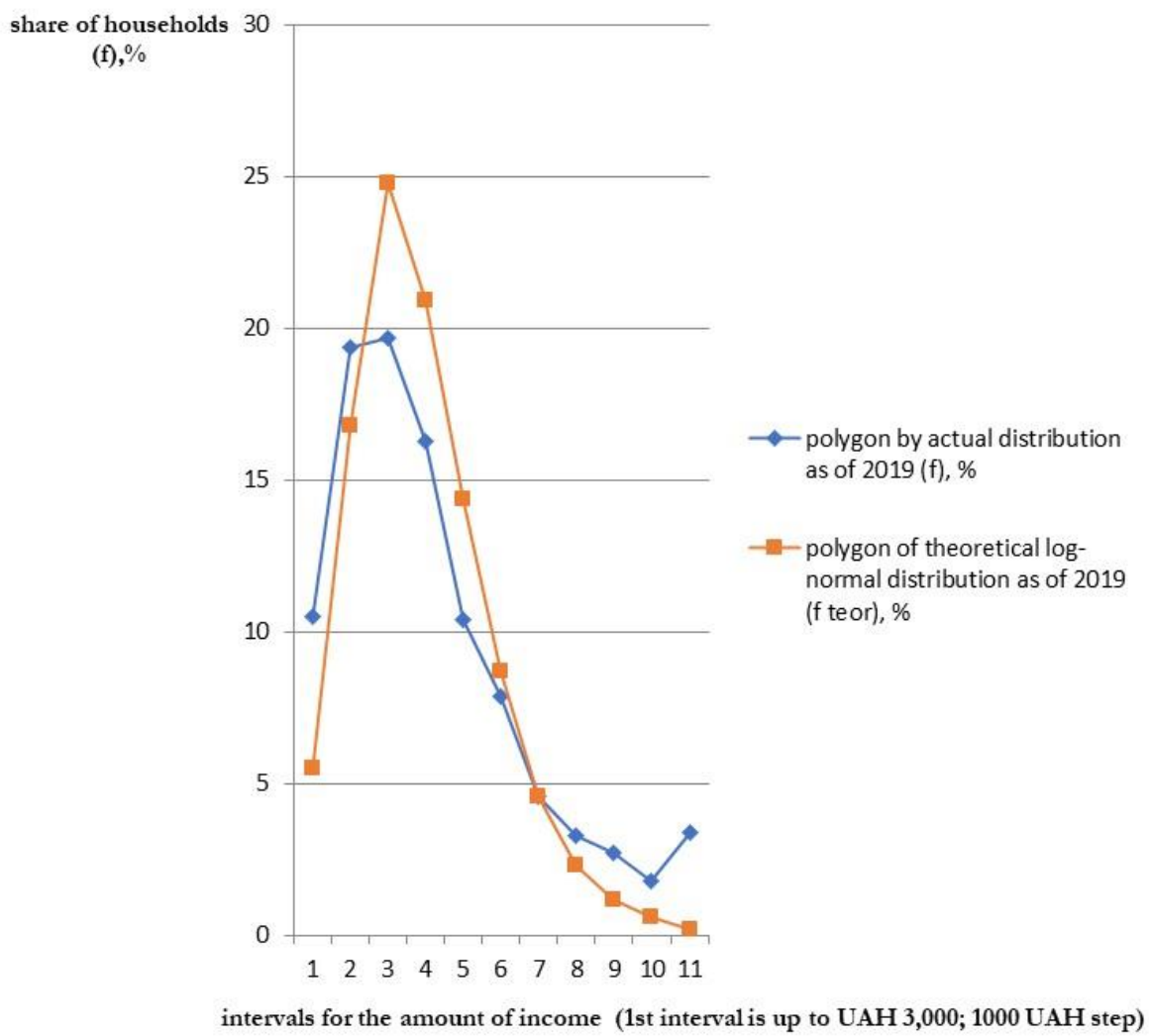

Figure 3. Polygon of household distribution according to the level of per capita equivalent total income Source: developed by the authors

The change in the social structure due to the implementation of digitization, the formation of destructive consequences, especially in the system of social and labour relations, are primarily related to the technological replacement of human labour in certain professions accompanied by rising unemployment, hollowing out of some social groups, and the change in the social stratification [10; 11]. For example, according to R. Collins, the implementation of computerization and the spread of information 
technology directly threatens the existence of the middle class, because it is its representatives that perform the functions of communicative activities [7]. Under digitalization, 'the transformation of super-complex and complex work into simple (from the standpoint of labour functions) has negative consequences directly for the middle class' [11]. Intensive saturation of social production with information systems, elements of artificial intelligence, cloud technologies, etc. are accompanied by multifaceted and large-scale dismissal in employment and, as a consequence, hollowing out of human potential and the loss of human capital [11].

According to the implementation of programmes and plans for digitalization of the economy of Ukraine [6; 28], the implementation of modern information and communication technology is accompanied by the dismissal of a significant number of employees. The majority of them are middle class by professional groups and the employment pattern. In Ukraine, due to objective reasons related to the economic, technological, information and communication lag behind the leading countries of the world, the negative consequences of possible changes in social stratification have not yet been clearly and unambiguously manifested. However, under the accelerated digitalization according to the target scenario of the national economic development in the short term (until 2025), the risks of dismissal as the probability of job loss among the economically active population can reach 0.222 , which is about 3.24 million people [9; 16]. About half of employees, who lose their jobs first according to professional groups, belong to the middle class. Under these conditions, the share of the middle class in terms of quality will decrease by $6.7 \%$ compared to 2019 . Taking into account the requirements of the combinational criterion, the core of the middle class will decrease by about $4 \%$ and will be only $11.4 \%$.

Despite the significant difference in the criteria for determining the middle class, according to the majority of the scientific and expert communities in highly developed countries, its share should be about $55-65 \%$ of the adult population. Only under these conditions is the middle class a factor of economic and social sustainable development, social stability of society.

In Ukraine, the share of the middle class has become 4-5 times smaller during the last decade due to objective reasons. It changed over the last decade from 13.8\% (2010) to $15.1 \%$ (2019), and according to forecast, the share of the middle class may be reduced by another $4.0 \%$ in the next five years and may be only $11.4 \%$ under the condition of accelerated digitalization in 2025 .

In Ukrainian realities, due to the small size of this social stratum, the possibilities of its full influence on economic and social sustainable development are quite limited, its significance and social role are small, the opportunities to fully perform its inherent functions in society are insufficient.

\section{Conclusions}

Being the basis of an economically efficient society, the middle class is seen as a significant driver of sustainable development including economic, social, and spiritual progress. At the same time, the prerequisite for providing conditions for the formation, development, and growth of this social group in society should be a high level of 
economic development and welfare of the population, which is possible under the following conditions:

- ensuring stable economic growth;

- promoting the development of small and medium enterprises and businesses, the emergence of family private enterprises and farms;

- improving the level and quality of life of the population, creating conditions for increasing income, accumulation, and legalization of assets;

- reducing polarization of society due to reduction of the income gap between highincome and low-income segments of the population;

- financial and information support, strengthening the social position of representatives of scientific, technical, humanitarian, and creative intelligentsia, improving their social status and material security;

- formation and development of state programmes and mechanisms of state economic policy to neutralize the negative impact of digitalization in the field of employment.

The research was performed within the research work of the Institute of Industrial Economics of the National Academy of Sciences of Ukraine "Formation of a new quality of working life under the influence of digital transformations" (state registration number 0121U111954, 01.06 - 31.12.2021).

\section{References}

Aleksandrova O., 2011, The middle class as a factor in ensuring stability in modern Ukraine, http://elibrary.kubg.edu.ua/id/eprint/836/1/Aleksandrova_serednij\%20klass_2011.pdf $(25.12 .2020)$.

Alekseenok A., 2014, Theoretical and methodological approaches to the study of the structure of the middle class, in: Bulletin of State and Municipal Administration, 2/1 (12), p. 52-57.

Aristotel, 1983, Works, Vol 4, Moscow: Mysl, p. 376-644, http://rudocs.exdat.com/docs/index515662.html?page $=4(30.10 .2020)$.

Balvociute R, 2020, Social Assistance for Poverty Reduction in the EU Countries: An Aspect of SocioEconomic Sustainability, in: European Journal of Sustainable Development, 9, 1, 469-480, https://ecsdev.org/ojs/index.php/ejsd/article/view/1003/996 (25.01.2021).

Bulieiev I., 2020, Society, middle class, digital economy: state and prospects of development: scientific report, Kyiv.

Cabinet of Ministers of Ukraine, 2018, On approval of the Concept of development of the digital economy and society of Ukraine for 2018-2020 and approval of the action plan for its implementation, Document 67-2018-p, https://zakon.rada.gov.ua/laws/show/67-2018-\%D1\%80\#Text (9.01.2021).

Collinz R., 2009, Technological substitution and crises of capitalism: exits and dead ends, https://commons.com.ua/uk/tehnologicheskoe-zameshhenie-i-krizisy/(12.02.2021).

How many Ukrainians consider themselves the middle class, 2020, https://gazeta.ua/ru/articles/economics /_skolko-ukraincev-schitayut-sebya-srednim-klassom/948032_(22.01.2020).

Khandii O., Shamileva L., 2019, The impact of digital transformations on the economy and the workplace: socio-economic risks and consequences, in: Economic Herald of the Donbas, 3(57), p. 181-188.

Kolot A., 2018, Socio-labor sphere in the coordinates of the new economy: empowerment and new threats. Socio-labor sphere in the conditions of formation of the new economy: global challenges and dominants of development: coll. thesis add. participants of the round table, May 15. 2018, Kyiv: KNEU, p. 7-15.

Kolot A., Herasymenko O., 2019, Socio-labor development in the XXI century: the nature of global change, new opportunities, constraints and challenges, in: Demography and social economy, 1, p. 97-125, http://nbuv.gov.ua/UJRN/dse_2019_1_9_(11.12.2020). 
Libanova E., Cherenko L., Vasyliev O., Reut A., 2014, Middle-income population as a basis for the formation of the middle class in Ukraine, in: National security and defense, 1-2, p. 79-96.

Makeiev S., 2010, Socio-economic stratification in Ukraine: inadequate estimates, erroneous priorities, Ukrainian Society 1992 - 2010. Sociological monitoring, Kyiv: IS NAN Ukrainy, p. 119-128.

Moroz N., 2013, The middle class as a necessary condition for the development of civil society in Ukraine, $\begin{array}{lllll}\text { in: } \quad \text { Severyansky } & \text { chronicle, } & 2, & \text { p. } & 112-118 \text {, }\end{array}$ http://dspace.nbuv.gov.ua/bitstream/handle/123456789/57273 /12-Moroz.pdf?sequence=1 (21.11.2020).

Novikova O., Ostafiichuk Y., Khandii O., 2019, Social justice and economic efficiency of the modern labour market, in: Baltic Journal of Economic Studies, Vol. 5, 3, p. 145-151, DOI: https://doi.org/10.30525/2256-0742/2019-5-3-145-151. (22.01.2021).

Novikova O., Shamileva L., Shastun A., 2020, Prospects for changes in the labor sphere in the digitalization of the economy in the inertial and target scenario, in: Economic Herald of the Donbas. 2, p. 187-199, doi: 10.12958/1817-3772-2020-2(60)-187-199 (19.01.2021).

Razumkov Center, 2014, The middle class in Ukraine: identification criteria. Positions of experts, representation and selfdetermination of citizens, Kyiv: Zapovit, $64 \mathrm{p}$.

Razumkov Center, 2016, The middle class in Ukraine: ideas and realities, https://razumkov.org.ua/uploads/article/2016_Seredn_klas.pdf_(10.12.2020).

Rydzewski P., 2020, Immigration and Social Aspects of Sustainable Development. The Case of Germany, in: Problemy Ekorozwoju - Problems of Sustainable Development, vol.15, no 1, 25-31, DOI: 10.35784/pe.2020.1.03 (25.02.2021).

Semenenko I., Khandii O. Forced migration in Ukraine and reality of sustainable development goals achievement. Problemy Ekorozwoju - Problems of Sustainable Development. 2018. Vol. 13, No 1. P. $165-172$.

Sobolev A., 2013, Methodological approaches to defining the criteria for the middle class, in: Politics and Society, 1(97), p. 76-80.

State Statistics Service of Ukraine, 2010-2019, Expenditures and resources of households in Ukraine in 2010-2019: Statistical collection, Kiev: State Statistics Service of Ukraine.

State Statistics Service of Ukraine, 2011-2020, Self-assessment of households in Ukraine of the level of their income (according to a sample survey of households) in January 2011-2020: Statistical collections, Kiev: State Statistics Service of Ukraine.

State Statistics Service of Ukraine, 2019, Economic activity of the population of Ukraine for 2010-2018: Statistical collection, Kiev: State Statistics Service of Ukraine.

State Statistics Service of Ukraine, 2020, Labor force in Ukraine, 2019: Stat. collection, Kiev: State Statistics Service of Ukraine, http://www.ukrstat.gov.ua/druk/publicat/kat_u/2020/zb/07/zb_r_s_2019.pdf_(2.02.2021).

The middle class in Ukraine. Goals and objectives, 2015, in: Development of the middle class. Public initiative, https://www.middleclass.org.ua/sredniy-klass-v-ukraine-tseli-i-zadachi/_(2.02.2021).

Tkachenko T., 2007, The middle class in the social structure of society, in: Economic Bulletin of NTUU "KPI", 4, p. 21-23.

Ukrainian Institute of the Future, 2018, Ukraine 2030E - a country with a developed digital economy, https://strategy.uifuture.org/kraina-z-rozvinutoyu-cifrovoyu-ekonomikoyu.html (11.01.2021).

Zaslavskaya T., Gromova R., 1998, On the question of the "middle class" in Russian society, in: The world of Russia, 4, p. 3-22. 